\title{
THE INFLUENCE OF ATORVASTATIN ON OMENTIN-1 LEVEL AND INSULIN RESISTANCE IN PATIENTS WITH CORONARY ARTERY DISEASE AND OBESITY
}

\begin{abstract}
Summary. Adipose tissue is a powerful endocrine organ, which synthesizes significant amount of biologically active substances adipokines. Due to adipokine dysfunction, a spectrum of diseases associated with obesity appears, namely, coronary artery disease, diabetes mellitus, hypertension and oncology. Hyperinsulinemia and insulin resistance play a significant role in pathogenesis of cardiometabolic complications in patients with obesity. They trigger a pathological cascade of reactions leading to cardiovascular diseases. Omentin-1 possesses anti-atherogenic action and it can modify peripheral effects of insulin.

The aim of the study - to analyze changes in omentin-1 concentration and the condition of insulin resistance in patients with coronary artery disease and obesity during atorvastatin treatment.

Materials and Methods. 55 patients with obesity were examined. They had general clinical examination; blood lipids, uric acid level and liver enzymes; glycated hemoglobin, glucose, insulin with the calculation of HOMA index and omentin-1 concentration was determined. Patients were divided into two groups: the group $1-20$ patients with obesity, who did not suffer from CAD and did not take atorvastatin, and the group 2 - patients with CAD and obesity, who took atorvastatin. Determination of these indices was performed for patients of the group 2 in dynamics in 12 months.

Results and Discussion. In the group of patients with CAD and obesity, who took atorvastatin, lipid levels were reliably lower, but levels of fasting glucose concentration, uric acid and liver enzymes were higher than in the patients who did not take the drug. Elevation of omentin-1 in blood serum was observed in 12 months in patients with CAD and obesity simultaneously with the increase in insulin level and the decrease in tissue sensitivity to it.

Conclusions. Intake of atorvastatin by patients with coronary artery disease and obesity is accompanied by elevation of insulin concentration, intensification of insulin resistance and increase in omentin-1 level.
\end{abstract}

Key words: obesity; adipokines; omentin-1; insulin resistance; HOMA index; ischemic heart disease.

INTRODUCTION Adipose tissue is a powerful endocrine organ that synthesizes significant amount of biologically active substances - adipokines, which can influence energy homeostasis, carbohydrate and lipid metabolism, blood pressure, angiogenesis, coagulation and functioning of the immune system. Due to adipokine dysfunction, a spectrum of diseases occurs, associated with obesity, namely, coronary artery disease, diabetes mellitus, hypertension and oncology.

Currently known hormones of fatty tissue are divided into pro- and anti-atherogenic by the influence on cardiovascular system. Proatherogenic cytokines include leptin, resistin, visfatin, TNF- $\alpha$, interleukin-6 and C-reactive protein. Adiponectin, vaspin and omentin-1 possess the opposite effects [1].

Hyperinsulinemia and insulin resistance play a significant role in pathogenesis of cardiometabolic complications in patients with obesity. They trigger a pathological cascade of reactions leading to cardiovascular diseases. Omentin-1 possesses anti-atherogenic action and it can modify peripheral effects of insulin [2].

Omentin-1 has a direct influence on inflammation and damage to the epithelium and increases transportation of glucose, stimulated by insulin, in adipocytes; it is considered a biomarker of obesity, atherosclerosis, insulin resistance, and type 2 diabetes mellitus. Thus, the decrease in its concentration is associated with the afore mentioned conditions [3].

In their research, ChenQianqian and co-authors observed dose-dependent elevation of omentin-1 level in patients with CAD during intake of atorvastatin [4]. Thus, the study of interconnection of omentin-1 level and insulin resistance in patients with CAD and obesity is a topical issue.

The aim of the study - to analyze changes in omentin-1 concentration and insulin resistance in patients with coronary artery disease and obesity during atorvastatin treatment.

MATERIALS AND METHODS 55 overweight or obese patients were selected for investigation. Patients were divided into two groups: the group 1 included 20 patients with obesity without clinical signs of CAD, and the group $2-35$ patients with CAD and obesity, who took atorvastatin. The groups were equal by gender and age. The degree and type of obesity were determined by WHO criteria and IDF (2015).

Diagnosis of CAD was considered verified by the results of coronarography and/or the presence of myocardial infarction in anamnesis more than three months before. Treatment of patients with ischemic heart disease was administered according to unified clinical protocol "Stable coronary artery disease" approved by the Ministry of Health of Ukraine No. 152, dated 02.03.2016 (with amendments 23.09.2016 No. 994 ), including atorvastatin in the dose $20-40 \mathrm{mg}$, patients of the group 1 did not take statins.

Lipid blood spectrum, biochemical indices and glycated hemoglobin $\left(\mathrm{HbA} 1_{\mathrm{C}}\right)$ were detected by generally accepted methods on automatic analyzer "BioSystems" (Spain) using original sets of reagents. The level of insulin in blood serum was determined on immunochemoluminescence analyzer "Immulite 2000" (Siemens, Germany) using proper reagents (Immulite 2000 Insulin, USA).

Index of insulin resistance (HOMA-IR ) was calculated by the formula:

HOMA-IR=fasting insulin $(\mu I U) / \mathrm{ml}$ fasting blood sugar level $(\mathrm{mmol} / \mathrm{l}) / 22.5$.

Omentin-1 concentration was determined by immunoenzymatic method using test system Omentin-1 RayBiotech (USA).

Indices of lipid, carbohydrate blood spectrum, liver enzymes, uric acid and omentin-1 in patients with CAD and obesity, taking atorvastatin (group 2), were determined in dynamics in 12 months of monitoring.

The results are given as mean values with statistical error. The values with normal distribution are presented as confidence interval (95\%); and the values, where distribution significantly differed from the norm, are presented as interval of $25 \%$ and $75 \%$ percentiles. Comparison of groups was performed by means of Mann - Whitney U-test. The results were considered statistically reliable at $p<0.05$. 
RESULTS AND DISCUSSION As it is seen from Table 1 , indices of transaminases, uric acid and glucose were reliably higher in the first group of patients with CAD and obesity, who took atorvastatin, unlike patients from the second group, who demonstrated higher BMI and waist circumference indices. The levels of triglycerides and glycated hemoglobin in the investigated groups reliably did not differ. Concentration of low-density lipoproteins, high-density lipoproteins and total cholesterol was reliably higher in the group of patients, who did not take atorvastatin.

In the group 2, reliable changes in lipid spectrum of the blood, liver transaminases and uric acid were not observed in a year of monitoring.

Concentration of fasting blood glucose level and glycated hemoglobin almost did not change; however, insulin level increased almost twice, which provoked increase in HOMAIR index.

Despite numerous advantages of statin therapy for cardiological patients, one of the negative influences on metabolism is the ability of atorvastatin to intensify insulin resistance and induce type 2 diabetes mellitus. Thus, patients with risk factors of type 2 diabetes mellitus development need thorough monitoring of glucose metabolism during hypolipidemic therapy.

The level of omentin-1, which is an anti-atherogenicadipokine, reliably increased throughout 12 months of atorvastatin intake in the dose of $20-40 \mathrm{mg}$ by patients with CAD and comorbid obesity from $0.87 \mathrm{ng} / \mathrm{ml}$ to $1.60 \mathrm{ng} / \mathrm{ml}, \mathrm{p}<0.05$ (Fig.2).

The obtained results enable to suppose two possible mechanisms of omentin-1 increase in these patients: a direct influence of atorvastatin or elevation of omentin-1 is of compensatory nature as a response to intensification of insulin resistance, most likely induced by the same atorvastatin. It should be noted that type 2 diabetes mellitus was diagnosed for the first time in two patients from the group 2 in 12 months of monitoring. Omentin-1 level in these patients constituted 0.26 and $0.086 \mathrm{ng} / \mathrm{ml}$ before onset of type 2 diabetes mellitus, which may indicate exhaustion of compensatory mechanisms for the regulation of insulin resistance indirectly via omentin-1.

CONCLUSIONS 1. In patients with CAD and obesity, who took atorvastatin, lipid spectrum was better than in patients with obesity without $C A D$ and drug intake, however, the

Table 1. Patients' characteristics

\begin{tabular}{|c|c|c|c|}
\hline Baseline Characteristic & \begin{tabular}{|c|} 
Group 1 \\
Non-CAD patients with obesity $(n=20)$
\end{tabular} & $\begin{array}{c}\text { Group } 2 \\
\text { CAD patients with obesity }(n=35)\end{array}$ & $\mathrm{P}$ \\
\hline Male, $\%$ & $74 \%(15)$ & $77 \%(27)$ & \\
\hline Age, years & $58.3(55.95-60.65)$ & $60.3(57.2-63.3)$ & $>0.05$ \\
\hline $\mathrm{BMI}, \mathrm{kg} / \mathrm{m}^{2}$ & $34(31.58-39.15)$ & $30.9(29.3-32.6)$ & $<0.01$ \\
\hline $\mathrm{WC}, \mathrm{cm}$ & $112(107.75-119.25)$ & $106.6(102.70-110.40)$ & 0.01 \\
\hline ALT, mmol/l & $11.05(9.25-15.7)$ & $24.7(15.90-38.90)$ & $<0.01$ \\
\hline $\mathrm{AST}, \mathrm{mmol} / \mathrm{l}$ & $20.65(18.85-24.23)$ & $28.9(20.50-33.10)$ & 0.01 \\
\hline Uric Acid, mmol/l & $291.5(258.65-324.31)$ & $373.9(342.20-405.70)$ & $<0.01$ \\
\hline $\mathrm{HDL}, \mathrm{mmol} / \mathrm{l}$ & $1.4(1.24-1.50)$ & $1.1(1.05-1.23)$ & $<0.01$ \\
\hline $\mathrm{LDL}, \mathrm{mmol} / \mathrm{l}$ & $3.4(3.10-3.76)$ & $2.5(2.20-2.82)$ & $<0.01$ \\
\hline Cholesterol, mmol/l & $5.62(5.19-6.05)$ & $4.2(3.92-5.06)$ & $<0.01$ \\
\hline Triglycerides, $\mathrm{mmol} / \mathrm{l}$ & $1.49(1.1-2.11)$ & $1.67(1.29-2.14)$ & $>0.05$ \\
\hline $\mathrm{HbA} 1, \%$ & $5.17(4.85-5.94)$ & $5.0(4.7-5.5)$ & $>0.05$ \\
\hline Glucose, $\mathrm{mmol} / \mathrm{l}$ & $5.27(4.9-5.64)$ & $6.1(5.46-6.45)$ & $<0.01$ \\
\hline Insulin, $\mu \mathrm{IU} / \mathrm{ml}$ & $9.93(7.88-11.98)$ & $8.9(5.31-14.4)$ & $>0.05$ \\
\hline HOMA-IR & $2.38(1.8-2.96)$ & $2.38(1.51-4.25)$ & $>0.05$ \\
\hline Omentin-1, ng/ml & $0.87(0.45-1.21)$ & $0.87(0.64-1.1)$ & $>0.05$ \\
\hline
\end{tabular}

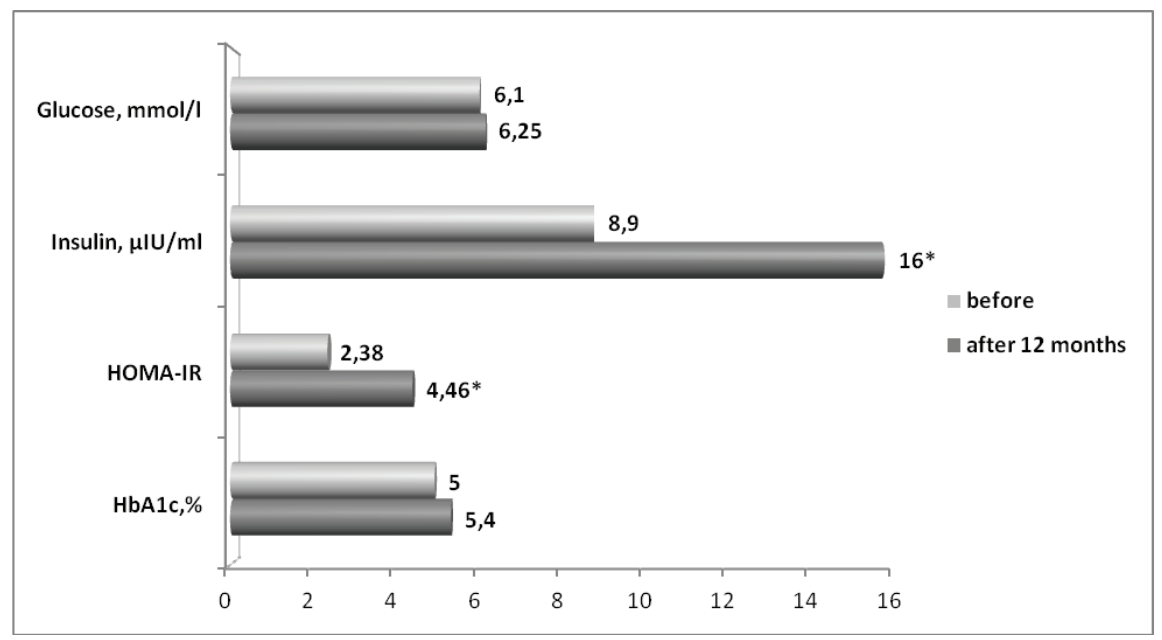

Fig.1. Changes in glucose metabolism indices in patients with CAD and obesity, who took atorvastatin. Note: *-p $<0.05$ 


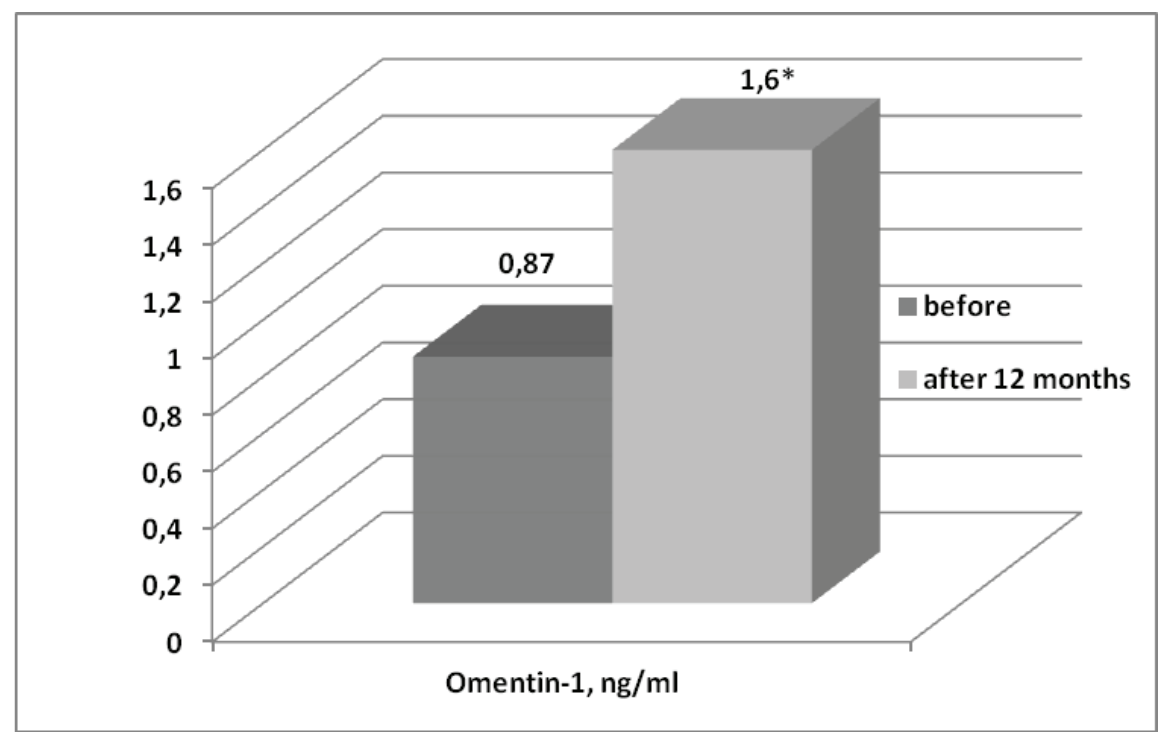

Fig.2. Dynamics of omentin-1concentration in patients with CAD and obesity, who took atorvastatin. Note: ${ }^{*}-p<0.05$

levels of blood sugar, uric acid and liver transaminases were higher. 2. It has been established that increase in insulin concentration in simultaneous elevation of omentin-1 level in blood serum of patients with CAD and obesity, who took atorvastatin, was accompanied by deterioration of tissue sensitivity to insulin.

\section{LITERATURE}

1. Smekal A. Adipokines and cardiovascular disease: A comprehensive revie / A. Smekal, J. Vaclavik. // Biomedical Papers. - 2017. - No. 161. - P. 31-40.

2. Counteractive effects of omentin-1 against atherogenesis / K. Watanabe, R. Watanabe, H. Konii [et al.]. // Cardiovascular Research. - 2016. - No. 110. - P. 118-128.
3. Місюра К. В. Циркуляторний оментин у осіб із різною масою тіла - критерій метаболічного ризику / К. В. Місюра, П. П. Кравчун // Клінічна ендокринологія та ендокринна хірургія. - 2017. - №3. - С. 60-68.

4. Effect of atorvastatin on serum omentin-1 in patients with coronary artery disease / C. Qianqian, S. Xingchen, Y. Meng [et al.]. // Coronary Artery Disease. - 2017. - No. 29. - P. 44-51.

Received 02.08.18

Email address for correspondence: maksymets.t@gmail.com

(อТ. А. Максимець Львівський національний медичний університет імені Данила Галицького

\section{ВПЛИВ АТОРВАСТАТИНУ НА РІВЕНЬ ОМЕНТИНУ-1 ТА ІНСУЛІНОРЕЗИСТЕНТНІСТЬ У ПАЦІЄНТІВ 3 ІШЕМІЧНОЮ ХВОРОБОЮ СЕРЦЯ ТА ОЖИРІННЯМ}

Резюме. Жирова тканина є потужним ендокринним органом, що синтезує значну кількість біологічно активних речовин адипокінів. Унаслідок адипокінової дисорункції виникає спектр захворювань, пов'язаних з ожирінням, а саме, ішемічна хвороба серця (IXC), цукровий діабет, гіпертензія та онкологія. Провідну роль у патогенезі кардіометаболічних ускладнень у пацієнтів з ожирінням відіграє гіперінсулінемія та інсулінорезистентність, які запускають патологічний каскад реакцій, що призводить до серцево-судинних захворювань, а оментин-1 має антиатерогенну дію та здатний модифікувати перифреричні ефекти інсуліну.

Мета дослідження - проаналізувати зміни концентрації оментину-1 та стану інсулінорезистеності у пацієнтів 3 ішемічною хворобою (IXC) та ожирінням під час лікування аторвастатином.

Матеріали і методи. Було обстежено 55 пацієнтів з ожирінням, яким проводили загальноклінічні обстеження, досліджували ліпіди крові, рівень сечової кислоти та печінкових ензимів, визначали глікований гемоглобін, глюкозу, інсулін із розрахунком індексу НОМА та концентрацію оментину-1. Хворих поділили на 2 групи: перша група - 20 пацієнтів з ожирінням, котрі не мали IXC та не приймали аторвастатин, друга - хворі на IXC та ожиріння, які приймали аторвастатин. Для другої групи проводили визначення цих показників у динаміці через 12 місяців.

Результати досліджень та їх обговорення. У групі пацієнтів з IXC та ожирінням, які приймали аторвастатин, були достовірно нижчі рівні ліпідів, проте концентрація глюкози натще, сечової кислоти та печінкових фрерментів була вища, ніж в осіб, котрі 
його не приймали. Через 12 місяців у хворих на IXC та ожиріння спостерігали зростання оментину-1 в сироватці крові паралельно зі збільшенням рівня інсуліну та зниженням чутливості тканин до нього.

Висновки. Прийом аторвастатину в пацієнтів з ішемічною хворобою серця та тлі ожиріння супроводжується підвищенням концентрації інсуліну, посиленням інсулінорезистентності та зростанням рівня оментину-1.

Ключові слова: ожиріння; адипокіни; оментин-1; інсулінорезистентність; індекс НОМА; ішемічна хвороба серця.

(ст. А. Максимец

Львовский национальный медицинский университет имени Данила Галицкого

\section{ВЛИЯНИЕ АТОРВАСТАТИНА НА УРОВЕНЬ ОМЕНТИНА-1 И ИНСУЛИНОРЕЗИСТЕНТНОСТЬ У ПАЦИЕНТОВ С ИШЕМИЧЕСКОЙ БОЛЕЗНЬЮ СЕРДЦА И ОЖИРЕНИЕМ}

Резюме. Жировая ткань является мощным эндокринным органом, который синтезирует значительное количество биологически активных веществ - адипокинов. Вследствие адипокиновой дисфункции возникает спектр заболеваний, связанных с ожирением, а именно, ишемическая болезнь сердца (ИБС), сахарный диабет, гипертензия и онкология. Ведущую роль в патогенезе кардиометаболических осложнений у пациентов с ожирением играет гиперинсулинемия и инсулинорезистентность, которые запускают патологический каскад реакций, что приводит к сердечно-сосудистым заболеваниям, а оментин-1 имеет антиатерогенное действие и способен модифицировать периферические эффекты инсулина.

Цель исследования - проанализировать изменения концентрации оментина-1 и инсулинорезистености у пациентов с ишемической болезнью сердца (ИБС) и ожирением во время лечения аторвастатином.

Материалы и методы. Были обследованы 55 пациентов с ожирением, которым проводили общеклинические исследования, изучали липиды крови, уровень мочевой кислоты и печеночных фрерментов, определяли гликированный гемоглобин, глюкозу, инсулин с расчетом индекса НОМА и концентрацию оментина-1.

Больных разделили на 2 группы: первая группа - 20 пациентов с ожирением, которые не имели ИБс и не принимали аторвастатин, вторая группа - пациенты с ИБС и ожирением, принимавшие аторвастатин. Для второй группы проводили определение этих показателей в динамике через 12 месяцев.

Результаты исследований и их обсуждение. В группе пациентов с ИБС и ожирением, принимавших аторвастатин, были достоверно ниже уровни липидов, однако концентрация глюкозы натощак, мочевой кислоты и печеночных ферментов была выше, чем у пациентов, которые его не принимали. Через 12 месяцев у пациентов с ИБС и ожирением наблюдали повышение оментина-1 в сыворотке крови параллельно с повышением уровня инсулина и инсулинорезистентности.

Выводы. Прием аторвастатина у пациентов с ишемической болезнью сердца на фроне ожирения сопровождается повышением концентрации инсулина, усилением инсулинорезистентности и увеличением уровня оментина-1.

Ключевые слова: ожирение; адипокины; оментин-1; инсулинорезистентность; индекс НОМА; ишемическая болезнь сердца. 